\title{
İnşaat sektöründe oluşan iş değişiklik taleplerini azaltacak bir proje yönetim sistemi önerisi
}

\author{
A project management system proposal to reduce change orders in the \\ construction industry
}

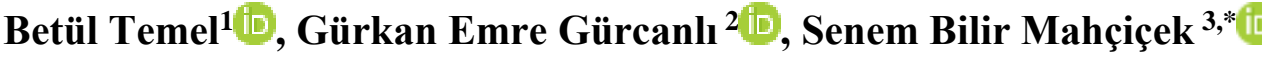 \\ 1,2,3 İstanbul Teknik Üniversitesi, İnşaat Fakültesi, İnşaat Mühendisliği Bölümü, 34469 İstanbul/TÜRKIYYE
}

\begin{abstract}
Özet
Hızlı artan nüfus, sosyo-kültürel ihtiyaçların değişimi, ekonomideki gelişim ve değişim inşaat sektörünün önemini zamanla arttırmıştır. Böylelikle, projelerin istenilen süre, kalite ve maliyette başarıyla gerçekleştirilmesini zorlaşmış; işinde tecrübeli, projeyi yönetebilecek kabiliyette proje yönetim firmalarının proje sürecine katılmalarını gerekli kılmıştır. Proje yönetim firmalarının projeyi yönetirken en çok karşılaştıkları sorun ise proje boyunca sıklıkla oluşan iş değişikliği talepleridir. $\mathrm{Bu}$ sebeple, sistematik bir iş değişikliği yönetimi ve iş değişikliğini azaltacak bir proje yönetim sistemi, projenin başarısı açısından hayati öneme sahip olmaktadır. Bu çalışmada, değişiklik taleplerine duyarlı, çeşitli sorunlar nedeniyle ortaya çıkan hak taleplerini azaltacak bir proje yönetim sistemi önerisi sunulmuştur. $\mathrm{Bu}$ sistem hazırlanırken proje yönetim firmalarının bir projenin başından sonuna kadar yapması gereken işler, literatür ve örnek projeler üzerinden belirlenmiş, tablolar halinde sunulmuştur. Ardından, proje yönetim sistemlerinde revizyonlar yapılarak iş emri değişikliklerinin proje üzerindeki negatif risklerinin düşürülmesi ve iş değişikliklerinin azaltılması hedeflemiştir. Sunulan sistem önerisinden proje yönetimi alanında çalışan tüm proje taraflarının faydalanacaklarına inanılmaktadır.
\end{abstract}

Anahtar kelimeler: Proje yönetim firması, Proje yönetim süreçleri, Hak talepleri, Verimlilik

\section{Giriş}

İnşaatlar, insanlığın var oluşundan beri temel yaşam gereksinimlerin bir sonucu olarak ortaya çıkmıştır. Daha sonrasında ise ilerleyen endüstriyel devrimler ile başta fabrikalar, ulaştırma yapıları, eğitim ve sağlık ihtiyaçlarını karşılayacak yapılar olmak üzere çeşitli inşaat projelerine ihtiyaç duyulmuştur. İnşaat sektörü ülkemizde de lokomotif sektör özelliği göstermektedir. Doğrudan veya dolaylı olarak 200'ün üstünde farklı sektörlere istihdam sağlayarak ve katma değer yaratarak "ekonominin kaldıracı" olma özelliğini de taşımakta [1], öte yandan inişli çıkışlı özelliği dolayısıyla ekonomideki kırılganlığı da beslemektedir. İnşaat sektörünün belirsiz parametrelerden etkilenmesi ve

\begin{abstract}
The rapidly increasing population, change of social-cultural needs, development and change in economy have increased importance of construction industry over time. Furthermore, more complicated projects have begun to be constructed and to realize them successfully in desired time, quality and cost has become difficult. These require involvement of experienced project management companies. Conversely, the most common problem faced by project management companies while managing projects is change order requests. Thus, a systematic change order management and a project management system that reduce change orders is vital. In this study, a change order sensitive project management system for change order requests was established in order to reduce claims arising due to various problems in construction projects. For preparation of this system, steps should be performed by project management companies from the beginning to the end of construction projects were determined through literature review and a case study. Results were presented in tabular form. Afterwards, by making revisions in examined project management system and its process flow, it was aimed to reduce change orders and their negative effects on projects. It is believed that all parties in construction projects will benefit from presented system and recommended flowchart.
\end{abstract}

Keywords: Project management company, Project management processes, Claims, Productivity

ekonomiye karşı olan hassasiyeti, sektöre karşı olan güveni giderek azaltsa da inşaat sektörüne yapılan yatırımların hacmi, büyüklüğü ve karmaşıklığı her geçen gün artmaktadır. Bu sebeple mal sahibi ve yatırımcılar güvensiz ve riskli bir alanda kendilerine daha güvenli bir ortam yaratmak için büyük ve karmaşık yapıdaki yatırımlarında oluşabilecek riskleri öngörebilecek, bu riskleri yönetebilecek, gerektiğinde önleyebilecek veya azaltabilecek, özetle projelerinde hedefledikleri zaman, kalite ve bütçeyi yakalayabilecek sektöre hâkim profesyonellere ihtiyaç duymaktadırlar. Diğer bir değişle farklı iş ortaklarının tek bir şantiyede birlikte üretim yapmak zorunda olduğu inşaat sektöründe projelerin etkin bir şekilde

\footnotetext{
* Sorumlu yazar / Corresponding author, e-posta / e-mail: sbilir@itu.edu.tr (S. Bilir Mahçiçek)

Geliș / Recieved: 22.03.2021 Kabul / Accepted: 26.04.2021 Yayımlanma / Published: 27.07.2021

doi: 10.28948/ngmuh.901239
} 
yönetimi çok önemlidir [2]. Bu problemler de proje yönetim firmalarının inşaat projeleri sürecine katılmalarını kaçınılmaz bir hale getirmiştir.

İnşaat sürecinin her evresinde yaşanması muhtemel bu iş değişikliklerinin proje sürecinde meydana gelmesi, projenin performansını önemli ölçüde etkilemektedir. Bu sebeple, sistematik bir iş değişikliği yönetimi ve iş değişikliğini azaltacak bir proje yönetim sistemi, projenin başarısı açısından büyük bir öneme sahiptir. Bu çalışmada inşaat projelerinde görev alan proje yönetim firmalarının yapması gereken görevler literatürde çalışması ile incelenmiş ve örnek proje üzerinden genişletilerek sunulmuştur. Ayrıca, proje boyunca oluşan iş değişikliği taleplerinin azaltılmasına yönelik bir proje yönetim sistemi önerisi hazırlanmıştır. Önerilen proje yönetim sisteminin hem proje yönetim firmalarına hem de profesyonel bir proje yönetim firması ile çalışma imkânı bulunmayan firma ve proje yöneticilerine iş değişikliklerini azaltabilmek için yol gösterici olacağı düşünülmektedir.

\section{Literatür araştırması}

Proje yönetim firmalarının en çok karşılaştıkları sorunların başında proje boyunca çok sık oluşan iş değişikliği talepleri gelmektedir. İnşaat proje yönetimi kaynaklarında "Change Order" veya uluslararası FIDIC sözleşmelerinde "Variation Order" olarak tanımlanan ve özel bir yer ayrılan değişiklik taleplerinin hacmi, bazen neredeyse bir toplam proje maliyetinin \%8'ine kadarına ulaşmaktadır [3]. Thomas ve arkadaşları [4] çalışmalarında iş değişikliklerinin projenin yaşam döngüsünün her aşamasında kaçınılmaz olduğunu vurgulamışlardır. Saiti ve diğerleri [5] inşaat projelerinde karşılaşılan iş değişikliklerini, projenin tipi, büyüklüğü, yapılış amacı ne olursa olsun inşaatın her evresinde ortaya çıkabilen ve tüm inşaat projelerinin maruz kaldığı kaçınılması mümkün olmayan ortak bir konu olarak tanımlamışlardır.

Özellikle son otuz yıldır yoğunlaşan çalışmalar, inşaat projelerinde yaşanan iş değişikliklerini ve iş değişiklik taleplerini azaltmaya yönelmektedir. Arain [6], iş değişikliklerini azaltmaya yönelik yaptığı araştırmada projenin daha tasarım aşamasında devreye alınmasının projedeki verimliliği arttıracağını, iş değişikliklerini azaltacağı, ayrıca profesyonellerin daha bilinçli ve efektif karar vermelerini sağlayacağını belirtmiştir. Motava ve diğerleri [7], inşaat sektöründeki projelerde tasarım aşamasında yaşanan potansiyel, olası iş değişikliklerini öngörebilen ve meydana gelmeden önce proje paydaşlarının çözüm üretebilmesine firsat yaratan bir sistem modeli üzerinde çalıştılar. Isaac ve Navon [8] çalışmalarında, inşaat sektöründe yaşanan bu değişikliklerin kontrolü için müşterinin istekleri ve ihtiyaçları ile yapının tasarımı arasında bağlantılar oluşturan araçlar önerdiler. Motawa ve diğerleri [7] çalışmalarında, iş değişikliklerinin tahmini ve değişiklik yönetimi için bulanık mantıkla ve değişiklik tahmin modeli ile birleştirilmiş proaktif ölçümlemeler önermiş̧lerdir. Bir diğer çalışma Ssegawa ve diğerleri [9] tarafindan Botsvana'daki inşaat projelerinde yaşanan değişikliklerinin oluşma sıklığını, sebeplerini, her değişiklik çeşidine göre iş değişikliği sebeplerini yaratan proje taraflarını ve iş değişikliklerinin yarattığı etkileri araştırmak için yürütülmüsştür. Memon ve diğerleri [10] yilında Malezya'daki inşaat projelerinde değişikliklerin oluşmasında etkili en önemli sebeplerin ne olduğunu ve iş değişikliklerinin proje üzerinde yarattığı etkileri bulmayı hedefleyen araştırma çalışması yapmışlardır. Literatürde iş değişikliği taleplerinin nedenlerini ve çeşitlerini araştıran farklı birçok çalışma bulunmaktadır [11-15]. Şimdiye kadar sunulan çalışmalarda inşaat projelerinde yaşanan süre uzamalarının sebeplerinin iş değişiklik taleplerinin sebepleri ile benzerlik gösterdiği görülmektedir. Projelerdeki süre uzamalarının, iş değişikliği taleplerinin bir sonucu olduğunu söylemek yanlış olmayacaktır.

İş emri değişikliğinin ortaya çıkmasını minimize etmeye çalışmak kadar, ortaya çıkması durumunda proje üzerindeki negatif etkilerini azaltabilmek için hak talebi sürecinin başarılı bir şekilde yönetilmesi de önemlidir. Bu anlamda, Charoenngam ve diğerleri [16] yılında iş emri değişikliklerinin ortaya çıkması sonrasında başarılı bir şekilde yönetilebilmesini hedefleyen, iş değişikliği emrinin dokümantasyonunu, projedeki farklı disiplinler arasındaki güçlü iletişim ve koordinasyonu ve iş değişikliği emri iş akış şemasını destekleyen internet tabanlı iş değişikliği emri yönetim sistemi konusunda çalışma yapmışlardır. Alnuaimi ve diğerleri [17] yılında Umman'daki kamu projelerinde meydana gelen iş değişikliklerinin sebeplerini, etkilerini araştıran ve sonucunda da bu durumun azaltılmasını sağlayacak bir dizi önerilere getiren bir çalışma yapmışlardır. Taylor ve diğerleri [18] ise yaptıkları çalışmada ABD'deki Kentucky eyaletindeki karayolu projelerinde meydana gelen iş emri değişikliklerinin, proje planlama ve proje kapsamı belirleme sürecinin iyileştirilmesi yolu ile azaltılabileceğini ve önlenebileceğini savunmuşlardır. Son olarak, Jadhav ve Bhirud [19] çalışmalarında, Hindistan'daki inşaat projelerinde meydana gelen iş emri değişikliklerinin sebeplerini ve etkilerini araştırmış, elde ettikleri veriler ile iş emri değişikliklerinin nasıl önlenebileceği ve kontrol altında tutulabileceği konusunda öneriler getirmiştir.

Literatür taramalarında Türkiye'deki iş değişikliği yönetim sistemi ve iş değişikliğinin azaltılmasına yönelik çok fazla çalışmanın olmadığı görülmüştür İnşaat sektöründe sıkça yaşanan iş değişikliklerinin minimize edilebilmesi için öncelikle ortaya çıkış sebeplerinin ve proje üzerindeki etkilerinin çok iyi bilinmesi gerekir. Çünkü eğer ortaya çıkış sebepleri ortadan kaldırılabilir veya ortaya çıkması sonrası proje üzerinde oluşan etkisi azaltılabilir ise proje ancak o zaman istenilen başarıya ulaşabilecektir. Bu amaçla inşaat projelerinde meydana gelen iş değişikliklerinin hangi aşamada hangi sebepten ve kim tarafindan oluştuğu bakış açısı ile oluşum sebepleri tüm yönü ile bu çalışmada ele alınmaya çalışılmıştır. Bu makale ile inşaat sektöründe proje yönetimi alanında çalışan ve verimlilikleri arttırmayı hedefleyen tüm tarafların kullanımı için değişiklik taleplerine azaltacak bir proje yönetim sistemi önerisi getirilerek literatürdeki boşluğun giderilmesi hedeflenmiştir. 


\section{3 Çalışmanın yöntemi}

Bu makale, iş değişiklik taleplerine inşaat proje yönetimi açısından öneriler getirme amacı taşıdığından dolayı, öncelikle dünyadaki en yaygın proje yönetim sistemleri hakkında bilgi verilmektedir. Ardından iş değişikliği taleplerinin meydana geliş sebepleri ve ortaya çıkması durumunda proje üzerindeki etkilerinin ne olacağı sunulmaktadır. Bir sonraki aşamada, inşaat sektöründe sıkça yaşanan iş değişikliklerinin önüne geçilmesi için uygulama aşamasında alınacak önlemlerden ziyade, iş sahibinin daha tasarım öncesi evreden proje yönetim firmasını seçmesi ile başlanarak ve sonrasındaki tasarım, ihale, yapım ve yapım sonrası evreyi de kapsayacak şekilde, projedeki tarafların hangi aşamalarda dâhil olduğuna bağlı olarak alması gereken önlemler örnek bir proje üzerinden belirlenmiştir. Son olarak ise iş değişikliklerinin meydana gelmesi sonrasında yönetim sisteminin ve sürecin nasıl işlediği konusu bir sistem önerisi ile anlatılmıştır.

\subsection{Dünyada proje yönetim kavramı ve standartları}

İnşaat sektöründe proje, eşi ve benzeri olmayan bir ürün sunmak, hizmet vermek veya sonuçlar ortaya koymak için üstlenilen geçici bir girişim olarak tanımlanmaktadır [20]. Projenin ihtiyaç duyduğu gereksinimlerin karşılanması amacı ile bilgi ve becerenin, araç ve gereçlerin, tekniğin, proje faaliyetleri ile ilişskilendirilmesi ve uygulanması işine de proje yönetimi denir [20]. Günümüzde ve dünya üzerinde yayın olarak kullanılmaya başlanan başlıca proje yönetim standartları şu şekildedir: Caupin, 2006 [21], Project Management Institute [22], Construction Management Association of America [23], PRINCE2 (English Project Management System) [24], IPMA (International Project Management Association) [25], P2M (Japanese Project Management System) [26].

\subsection{Inşaat projelerinde yaşanan iş değişiklik talepleri ve sebepleri}

İnşaat projeleri inşaat aşamasına geçmeden önce; tasarım öncesinde planlama ve bütçe oluşturma, tasarım evresi, ihale ve sözleşme evresi gibi birçok aşamadan geçer. Tüm bu aşamalarda alınan kararların bir kısmı kesin olmayan bilgiler, varsayımlar ve inşaat proje yöneticilerinin deneyimlerine dayanarak alınmış olabilir. Bu sebeple inşaat projelerinde iş emri değişikliklerine sıklıkla rastlanır. İş emri değişikliği, yürüklükte olan ana sözleşmenin kapsamında değişiklik, ekleme veya çıkarma yapabilmesine izin veren bir dizi talimatları içeren "değişiklik talebi" olarak adlandırılmaktadır [27]. Literatürde iş değişikliği emri birçok farklı çalışmada yine Revay'ın [27] tanımına benzer şekilde yapılmıştır $[28,29,30,31,32]$. İş değişiklik taleplerinin temel kaynaklarını bakacak olursak, bu kaynakları projeye katılan taraflara göre ve oluşum sebeplerine göre incelemekte yarar vardır.

İş sahibi, projenin sözleşme kapsamını ve iş programını kavramakta zorluk çekmesinden ötürü iș emri değişikliklerinin oluşmasına sebep olabilir; yüklenici ise iyileştirme yapmanın gerektireceği zamanı iş sahibinin tasarruf etmeyi kabul etmek istemesini firsat bilerek veya yaptığ 1 kusurlu işleri düzeltmekten kaçınmasından ötürü uygun olmayan imalatlar yapar, bu da projede iş değişikliklerine sebep olur. Mimar, sözleşme eki olacak projeler arasındaki koordinasyonun eksik sağlanmış olmasından veya projelerde eksik bilgilerin olmasından ötürü inşaat sürecinde projenin sık sık duraklatılmasına sebep olur ve iş değişiklikleri meydana getirir. Birçok çalışmada iş değişikliği taleplerinin kaynakları incelenmiş ve bu çalışma kapsamında Tablo 1'de sunulmuştur.

\section{3 İş değişikliklerinin proje üzerindeki temel etkileri}

Yine literatürdeki çalışmalar incelendiğinde iş değişiklerinin proje üzerinde proje bütçesi, proje süresini, iş gücü verimliliği, işin kalitesi, işçi sağlığı ve güvenliği, ödemelerin zamanında yapılamaması, ötelenmesi, imalatın düzeltilmesi veya yıkılıp yeniden yapılması, firmanın namına leke getirmesi, yöneticiler arasındaki ilişkilerin zayıflaması ve ikili ilişkiler arasında anlaşmazlıkların yaşanması gibi çeşitli etkiler bıraktığı görülmektedir [10, 33].

Örneğin, Taiwan'da yapılan araştırmaya göre, Kamu İşlerinde iş değişikliklerinden kaynaklı oluşan proje bütçe artışı, projenin toplam bütçesinin \%10-17'si oranındadır [39]. Bir başka örnekte ise inşaat projelerinde iş değişikliklerinden kaynaklı proje maliyetinin ortalama \%11 ile \%15 civarında arttığı sonucuna varılmıştır [40]. Zeitoun ve Oberlender [41] inşaat projelerinde yaşanan değişikliğin proje süresini, projenin sözleşme ekinde anlaşmaya varılan ve hedeflenen sürenin $\% 9$ u kadar uzatabileceğini belirtmişlerdir. Yapılan literatür taramasında inşaat sürecinde yaşanan iş değişikliklerinin, projenin en önemli iki parametresi olan proje bütçesini ve süresini ortalama $\% 10$ ile $\% 15$ arasında arttırdığı görülmüștür [39-41].

$\mathrm{Bu}$ çalışma kapsamında iş değişikliklerini azaltmaya yönelik bir yönetim sistemi önerileceği için iş değişikliklerine proje yönetimi açısından bakılmış ve iş değişikliklerinin proje üzerinde etkileri 5 ana grup altında ele alınmıştır. Bu ana gruplar oluşturulurken proje yönetim firmalarının inşaat projelerindeki rolünün önemi de göz önüne alınmıştır. Zira, Katar'da yapılan bir çalışmada 22 adet proje ve 1122 adet iş değişikliği üzerinden elde edilen verilerden inşaat projelerinde yaşanan iş değişikliklerinin bütçe artışı üzerinde ne kadar etkisi olduğunu analiz edilmiş ve iş değişikliğinin bütçe üzerindeki yarattığı artışa en çok sebep olan tarafin İş Sahibi, diğerlerine kıyasla en az artışa sebep olan tarafin ise Proje Yönetim Firması/Danışman olduğu belirtilmiştir [38]. Bu bağlamda, bu makale kapsamında iş değişikliklerinin proje üzerindeki etkileri proje yönetim mantığına uygun olacak şekilde proje bütçesi, proje süresi, işgücü verimliliği, taraflar arasındaki ilişkiler ve yapılan işin kalitesi üzerindeki etkisi olmak üzere belirlenmiştir. 
Tablo 1. Literatürdeki iş değişikliği talepleri ve kaynakları

\begin{tabular}{|c|c|c|c|c|c|c|c|c|c|}
\hline [10] & [34] & [11] & [35] & [5] & [36] & {$[37]$} & [9] & [38] & [19] \\
\hline $\begin{array}{l}\text { Sözleşme eki, iş } \\
\text { programında } \\
\text { değişiklik ve } \\
\text { yeniden } \\
\text { düzenleme } \\
\text { yapılması }\end{array}$ & $\begin{array}{l}\text { Tasarım } \\
\text { hataları }\end{array}$ & $\begin{array}{l}\text { Tasarımın } \\
\text { yetersiz } \\
\text { olması: }\end{array}$ & $\begin{array}{l}\text { Tasarım ve } \\
\text { şartnamelerin } \\
\text { eksiksiz } \\
\text { hazırlanmaması }\end{array}$ & $\begin{array}{l}\text { İş sahibi, \%82.5 oran } \\
\text { ile finansal } \\
\text { problemlerinden, } \\
\text { \% } 76.5 \text { oran ile hizlı } \\
\text { ve doğru karar } \\
\text { verememesinden ve } \\
\text { tüm proje kapsamını } \\
\text { değiștirebilmesinden } \\
\text { ötürü, iş } \\
\text { değişiklilerine sebep } \\
\text { olur. }\end{array}$ & $\begin{array}{l}\text { Tasarımların } \\
\text { tamamlanmadan } \\
\text { inşaat } \\
\text { aşamasına } \\
\text { geçilen } \\
\text { projelerde } \\
\text { şartlara uygun } \\
\text { planlama } \\
\text { yapılmaması }\end{array}$ & $\begin{array}{l}\text { Tasarımın } \\
\text { tamamlanmadan } \\
\text { inşaat sürecine } \\
\text { geçilmesi }\end{array}$ & $\begin{array}{l}\text { Projelerin } \\
\text { teslim } \\
\text { metotlarından } \\
\text { biri olan } \\
\text { geleneksel } \\
\text { teslim } \\
\text { yönteminde iş } \\
\text { değişikliklerinin } \\
\text { daha sık } \\
\text { yaşandığı }\end{array}$ & $\begin{array}{l}\text { Tasarımsal } \\
\text { hatalar }\end{array}$ & $\begin{array}{l}\text { İş sahibinin } \\
\text { değişiklik, ek iş, } \\
\text { mevcut projelerde } \\
\text { değişiklik } \\
\text { yapılması talebi }\end{array}$ \\
\hline $\begin{array}{l}\text { Sözleşme } \\
\text { kapsamında } \\
\text { değişiklik, ekleme } \\
\text { ve çıkarmaların } \\
\text { yapılması }\end{array}$ & $\begin{array}{l}\text { Piyasa } \\
\text { şartlarındaki } \\
\text { değişiklik }\end{array}$ & $\begin{array}{l}\text { İş miktarında } \\
\text { yapılan ciddi } \\
\text { değişiklikler }\end{array}$ & $\begin{array}{l}\text { Tasarım } \\
\text { süreçlerine } \\
\text { yeterli zamanın } \\
\text { verilmemesi }\end{array}$ & $\begin{array}{l}\text { Proje yönetim } \\
\text { firması, \%95.5 oran } \\
\text { ile tasarımın eksik } \\
\text { veya hatalı } \\
\text { olmasından, \%90 } \\
\text { oran ile şartnamedeki } \\
\text { değişikliklerden, } \\
\% 87.1 \text { oran ile } \\
\text { yetersiz çizim } \\
\text { detaylarından, \%85 } \\
\text { oran ile tasarım } \\
\text { detaylarındaki } \\
\text { belirsiz ve } \\
\text { tutarsızlıklardan } \\
\text { ötürü iş } \\
\text { değişiklilerine sebep } \\
\text { olur. }\end{array}$ & $\begin{array}{l}\text { Projedeki } \\
\text { tanımlamaların } \\
\text { ve istenilen } \\
\text { taleplerin eksik } \\
\text { olması veya net } \\
\text { olmaması }\end{array}$ & $\begin{array}{l}\text { Projede kötü } \\
\text { işçilikten } \\
\text { kaynaklı } \\
\text { uygulama } \\
\text { hataları }\end{array}$ & $\begin{array}{l}\text { Tasarla-yap } \\
\text { modelinde } \\
\text { geleneksel } \\
\text { modele nazaran } \\
\text { daha az iş } \\
\text { değişiklikleri } \\
\text { yaşandığı }\end{array}$ & $\begin{array}{l}\text { Tasarımlardaki } \\
\text { tutarsızlıklar }\end{array}$ & $\begin{array}{l}\text { Yüklenicinin } \\
\text { tasarım } \\
\text { aşamasında } \\
\text { bulunmaması ve } \\
\text { bu yüzden yapım } \\
\text { aşamasında } \\
\text { tasarımları } \\
\text { anlamakta zorluk } \\
\text { çekmesi }\end{array}$ \\
\hline $\begin{array}{l}\text { İşs sahibinin } \\
\text { finansal } \\
\text { zorlanmaları ve } \\
\text { ekonomik } \\
\text { problemleri }\end{array}$ & $\begin{array}{l}\text { Çalışmanın } \\
\text { miktar ve } \\
\text { kapsamının } \\
\text { değişmesi }\end{array}$ & $\begin{array}{l}\text { Kalitenin } \\
\text { daha iyi } \\
\text { olması } \\
\text { konusunda } \\
\text { getirilen } \\
\text { öneriler }\end{array}$ & $\begin{array}{l}\text { Öngörülmeyen } \\
\text { olayların } \\
\text { oluşması } \\
\text { (beklenmeyen } \\
\text { zemin şartları, } \\
\text { olağan dışı hava } \\
\text { durumu, ülke } \\
\text { yönetiminin } \\
\text { değişmesi vb.) }\end{array}$ & $\begin{array}{l}\text { Yüklenici, \%90 oran } \\
\text { ile yetersiz } \\
\text { değerlendirme ve iş } \\
\text { tecrübesinden, } \\
\% 88.9 \text { oran ile } \\
\text { stratejik planlama } \\
\text { eksikliğinden, \%80 } \\
\text { oran ile malzeme } \\
\text { temin etmedeki } \\
\text { gecikmelerinden } \\
\text { ötürü iş } \\
\text { değișiklilerine sebep } \\
\text { olur. }\end{array}$ & $\begin{array}{l}\text { İş sahibinin } \\
\text { finansal } \\
\text { anlamda } \\
\text { zorlanması ve } \\
\text { ekonomik } \\
\text { zorluklar } \\
\text { yaşaması }\end{array}$ & $\begin{array}{l}\text { Çeşitli } \\
\text { sebeplerden } \\
\text { ötürü } \\
\text { malzemelerin } \\
\text { tedarik süresinde } \\
\text { yaşanan } \\
\text { ertelenmeler }\end{array}$ & & $\begin{array}{l}\text { Tasarımlarda } \\
\text { değişiklik } \\
\text { yapılması } \\
\text { talepleri }\end{array}$ & $\begin{array}{l}\text { Dizayn sürelerinin } \\
\text { yeterli ve gerçekçi } \\
\text { olmaması }\end{array}$ \\
\hline $\begin{array}{l}\text { İş sahibinin karar } \\
\text { verme sürecinde } \\
\text { hızlı ve efektif } \\
\text { davranamaması, } \\
\text { karar alma } \\
\text { süreçlerinin } \\
\text { uzaması }\end{array}$ & Dış faktörler & $\begin{array}{l}\text { Kullanıcı } \\
\text { ihtiyaçları }\end{array}$ & $\begin{array}{l}\text { Yüklenici } \\
\text { talebiyle ortaya } \\
\text { çıan } \\
\text { değişiklikler }\end{array}$ & $\begin{array}{l}\text { Bazı dış faktörler, } \\
\% 65 \text { oran ile } \\
\text { olağandışı hava } \\
\text { koşullarından, \%58 } \\
\text { ülkedeki ekonomik } \\
\text { şartların } \\
\text { değişmesinden, \%55 } \\
\text { ülkedeki hükümetin } \\
\text { değişmesinden ötürü } \\
\text { iş değişiklilerine } \\
\text { sebep olur. }\end{array}$ & $\begin{array}{l}\text { Malzeme ve } \\
\text { ekipmanların } \\
\text { tedarik ve } \\
\text { temininde } \\
\text { sıkıntıların } \\
\text { yaşanması }\end{array}$ & $\begin{array}{l}\text { Tasarımların iş } \\
\text { sahibi } \\
\text { ihtiyaçlarını } \\
\text { karşımamada } \\
\text { eksik kalması } 1\end{array}$ & & $\begin{array}{l}\text { Tasarımın } \\
\text { yetersiz olması }\end{array}$ & $\begin{array}{l}\text { Yüklenici ve proje } \\
\text { danışmanı/müşavir } \\
\text { arasındaki iletişim } \\
\text { kopukluğu }\end{array}$ \\
\hline $\begin{array}{l}\text { İşs sahibinin ikna } \\
\text { olmaması }\end{array}$ & $\begin{array}{l}\text { İşaat sahası } \\
\text { şartlarının } \\
\text { farklılık } \\
\text { göstermesi }\end{array}$ & $\begin{array}{l}\text { Güvenlik } \\
\text { hususları }\end{array}$ & $\begin{array}{l}\text { Yüklenicinin } \\
\text { malzeme ve } \\
\text { ekipman } \\
\text { temininde } \\
\text { gecikmeler } \\
\text { yaşaması }\end{array}$ & & & & & $\begin{array}{l}\text { Tasarımın iş } \\
\text { sahibi istekleri } \\
\text { ile uyumlu } \\
\text { olmaması }\end{array}$ & \\
\hline $\begin{array}{l}\text { İşs sahibi } \\
\text { tarafindan } \\
\text { sözleşme eki } \\
\text { şartnamelerde } \\
\text { değişiklik }\end{array}$ & $\begin{array}{l}\text { Mevcuttan } \\
\text { daha iyi bir } \\
\text { öneri } \\
\text { sunulması }\end{array}$ & $\begin{array}{l}\text { İşsahibinin } \\
\text { finansal } \\
\text { durumlarını } \\
\text { iyileștirme } \\
\text { arzusu }\end{array}$ & $\begin{array}{l}\text { Risklerin } \\
\text { dağılımının, } \\
\text { proje } \\
\text { gruplarının } \\
\text { kapasitesine } \\
\text { göre } \\
\text { yapılmaması }\end{array}$ & & & & & $\begin{array}{l}\text { Talep edilen } \\
\text { malzemelerin } \\
\text { mevcutta } \\
\text { olmaması }\end{array}$ & \\
\hline $\begin{array}{l}\text { Müşavir/danışman } \\
\text { tarafindan } \\
\text { tasarımlarda } \\
\text { değişiklik ve } \\
\text { düzenleme } \\
\text { yapılması }\end{array}$ & $\begin{array}{l}\text { Tasarım } \\
\text { tercihlerinde } \\
\text { değişiklikler } \\
\text { yapılması }\end{array}$ & $\begin{array}{l}\text { Tasarım } \\
\text { hataları }\end{array}$ & $\begin{array}{l}\text { Projedeki } \\
\text { risklerin proje } \\
\text { grupları } \\
\text { arasında } \\
\text { elverişsiz ve } \\
\text { bilinçsiz } \\
\text { dağıtımı, }\end{array}$ & & & & & $\begin{array}{l}\text { İş miktarında } \\
\text { ciddi derecede } \\
\text { yapılan } \\
\text { değişiklikler }\end{array}$ & \\
\hline $\begin{array}{l}\text { Sözleşme } \\
\text { dokümanlarında } \\
\text { çakışma ve } \\
\text { uyumsuzluk }\end{array}$ & $\begin{array}{l}\text { Sözleşme } \\
\text { şartları }\end{array}$ & $\begin{array}{l}\text { Yüzey } \\
\text { koşullarında } \\
\text { farklılık }\end{array}$ & $\begin{array}{l}\text { Yüklenicinin iş } \\
\text { değişiklik } \\
\text { talepleri }\end{array}$ & & & & & Plansal hatalar & \\
\hline $\begin{array}{l}\text { Tasarımların } \\
\text { karmaşı ve } \\
\text { kompleks } \\
\text { olmasından ve } \\
\text { tasarımların tam } \\
\text { olarak } \\
\text { anlaşılamaması }\end{array}$ & Koordinasyon & Tutarsızlıklar & $\begin{array}{l}\text { İș sahibi talebi } \\
\text { ile ortaya çıkan } \\
\text { değişiklikler }\end{array}$ & & & & & $\begin{array}{l}\text { Kapsamın iş } \\
\text { sahibi } \\
\text { tarafından } \\
\text { değiştirilmesi }\end{array}$ & \\
\hline $\begin{array}{l}\text { Yetersiz tasarım } \\
\text { detayları }\end{array}$ & & $\begin{array}{l}\text { Ekonomik } \\
\text { şartların } \\
\text { değișmesi }\end{array}$ & & & & & & $\begin{array}{l}\text { İş sahibinin } \\
\text { memnuniyetsiz } \\
\text { olması }\end{array}$ & \\
\hline
\end{tabular}


Tablo 1. Literatürdeki iş değişikliği talepleri ve kaynakları (devamı)

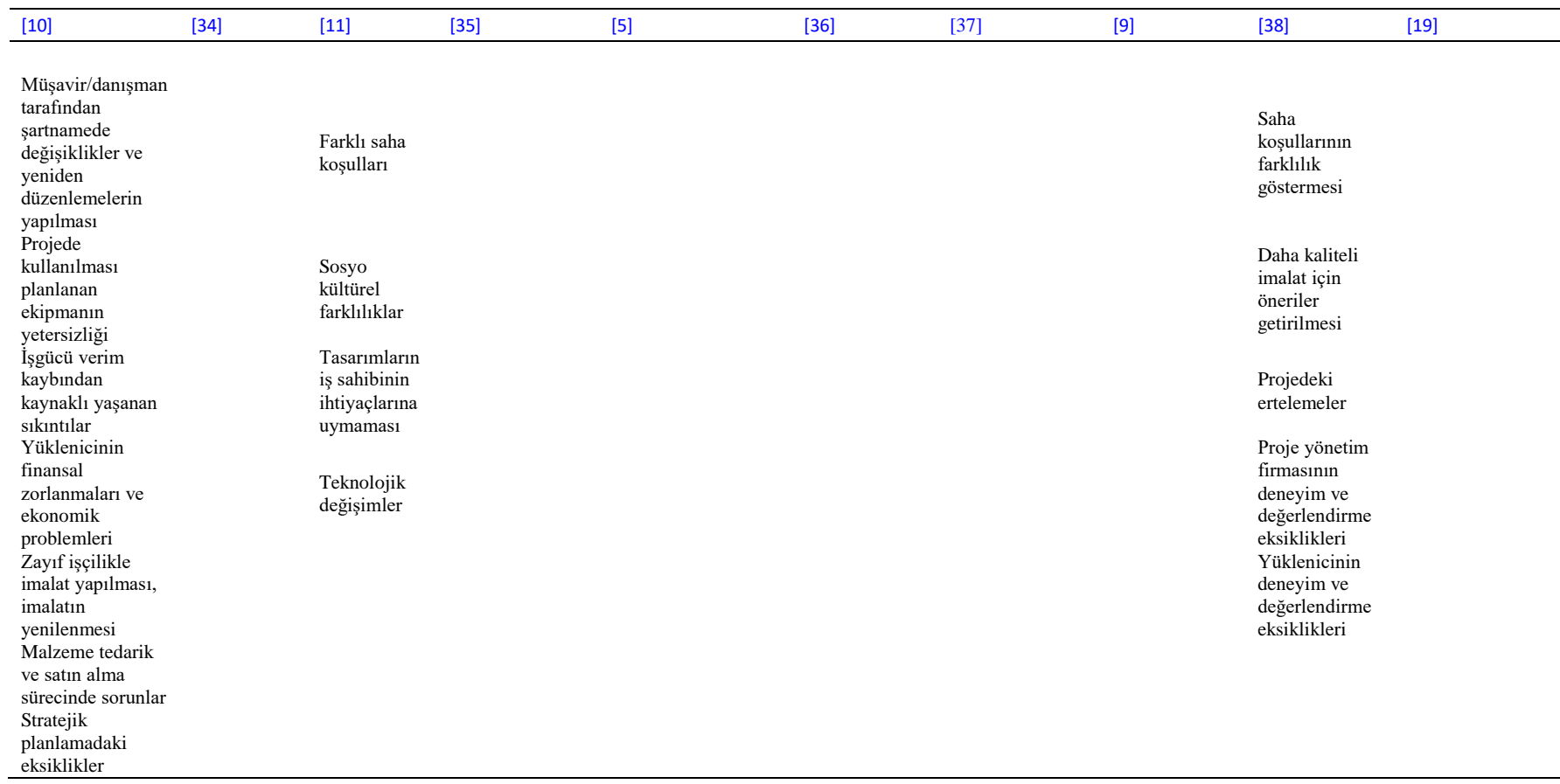

\section{4 Örnek bir proje yönetim firmasından iş değişiklikleri konusunda beklenen hizmetler}

İnşaat sektöründe yaşanan iş değişikliklerini minimize edecek proje yönetim sistemi önerisi getirilebilmesi için önceki bölümde literatür taraması yapılmış olup, iş değişikliğini ortaya çıkaran temel sebepler ve iş değişikliğinin ortaya çıkması sonucu proje üzerinde oluşturduğu etkiler incelenerek veriler toplanmıştır. $\mathrm{Bu}$ bölümde gerçek bir proje yönetim firmasının yazarlardan birinin çalıştığ 1 ve birçok iş değişikliği emrinin yaşandı ğ bir projedeki süreçlerdeki görev tanımı, iş kapsamı ve yönetim sisteminden bahsedilmiştir.

Tablo 2. Ön tasarım sürecinde proje yönetim firmasının yaptığı çalışmalar

Ön tasarım sürecinde proje yönetim firmasının yaptı̆̆ çalışmalar

1 İş sahibi istek ve gereksinimlerini belirleyerek proje kapsamını tanımlamak.

2 Kavramsal tasarımı geliştirmek

3 Yetkili kurumlardan gerekli izinlerin alınması için yatırımcıyı yönlendirmek

4 Temel iş programını oluşturmak.

5 Temel bütçeyi oluşturmak.

6 Proje müellifleri seçim kriterlerini belirlemek.

7 Yapılacak işle ilgili yetkin proje müelliflerinden teklif alıp, değerlendirerek iş sahibi onayına sunmak.

8 İş sahibinin onayladığı proje müellifleriyle yönetmelik ve şartnamelere uygun sözleşmeler yapmak.

9 Harita ve zemin etüt firmalarını belirleyerek çalışmaları başlatmak.

10 Temel proje organizasyon şemasını oluşturmak.

11 Temel risk analizlerini oluşturmak.

12 Proje el kitabını oluşturmak
Örnek proje bir endüstriyel sanayi tesisi projesi olup, Gebze/Kocaeli'nde inşa edilmiştir. Proje teslim yöntemi, tasarım-ihale-yapım olmakla birlikte sözleşme tipi anahtar teslim götürü bedeldir. Proje alanı yaklaşık $35.000 \mathrm{~m}^{2}$ ' dir ve 6 farklı bina tipi inşaatı söz konusu olmuştur. İş değişikliklerinin temel sebeplerinin ve yönetim sürecinin iyi anlaşlabilmesi için, süreci yöneten Proje Yönetim Firmasının yönetim sisteminin iyi anlaşılması gereklidir. Ön tasarım sürecinde proje yönetim firmasının yaptı̆̆ çalışmalar Tablo 2'de sıralanmıştır.

Tablo 3. Tasarım süreci boyunca proje yönetim firmasının yaptığı çalışmalar

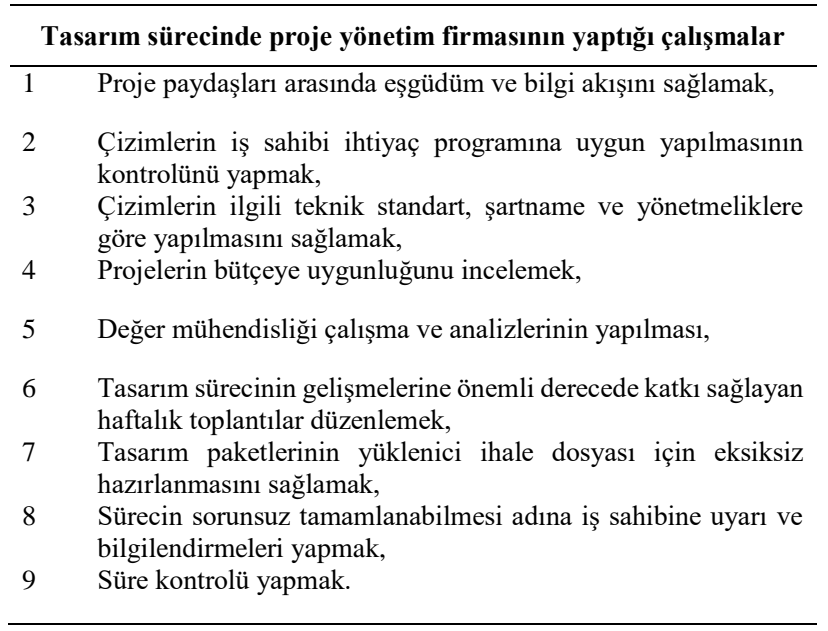

Tasarım gruplarının belirlenmesi sonrasında tasarım sürecine geçilmektedir. Tasarım süreci boyunca proje yönetim firmasının yaptığı çalışmalar Tablo 3'te sıralanmıştır. Yüklenicinin belirlendiği ihale sürecinde proje yönetim firmasının üstlendiği işler Tablo 4 'teki gibidir. 
Tablo 4. İhale sürecinde proje yönetim firmasının üstlendiği işler

\begin{tabular}{ll}
\hline & İhale sürecinde proje yönetim firmasının yaptığı çalışmalar \\
\hline 1 & İhale takvimini hazırlamak. \\
2 & İhale sürecini eksiksiz yönetmek. \\
3 & Uygun sözleşme türlerini belirlemek. \\
4 & Sözleşmeleri hazırlamak. \\
5 & Teknik şartnameleri hazırlamak. \\
6 & Birim fiyat tariflerini hazırlamak. \\
7 & Yüklenici ön yeterlilik kriterlerini belirlemek. \\
8 & İsteklilerin yeterliliklerini değerlendirmek. \\
9 & İhale dosyalarının ve zeyilnamelerin koordinasyonunu sağlamak. \\
10 & İhale ile ilgili isteklilerden gelen soruların cevaplamak. \\
11 & İsteklilerin tekliflerini analiz etmek. \\
12 & Uygun teklifleri belirlemek. \\
13 & $\begin{array}{l}\text { İhale ile ilgili değerlendirme ve raporları hazırlayarak iş sahibine } \\
\text { sunmak. }\end{array}$ \\
14 & $\begin{array}{l}\text { Sözleşme eki olarak hazırlanacak evrakların (iş programı, nakit } \\
\text { akışşeması, organizasyon şeması, teminat mektubu, iş sağlığı ve } \\
\text { güvenliği planı, kalite kontrol planı) takip ve kontrolünü yapmak. }\end{array}$ \\
15 & $\begin{array}{l}\text { Yükleniciye yer teslimi yapmak, bu konuda gerekli işlemleri takip } \\
\text { etmek ve koordinasyonu sağlamak. }\end{array}$ \\
\hline
\end{tabular}

Yapım döneminde ise proje yönetim firmasından beklenen görevler Tablo 5'te sıralanmıștır. İnşaat projelerinin tamamlanması ve iş sahibinin yapıyı işletmeye alması sonrası da proje yönetim firmasının görev tanımı ve iș kapsamı devam etmekte olup kapsamındaki ișler Tablo 6 'da sunulmuştur.

Tablo 5. Yapım döneminde proje yönetim firmasından beklenen görevler

\footnotetext{
Yapım sürecinde proje yönetim firmasının yaptığı çalışmalar

1 Sözleşme yönetimi

2 Şantiye kuruluşunu yönlendirmek, şantiye mobilizasyon planını oluşturulmasını sağlamak ve kontrol etmek

3 Şantiye organizasyon şemasının oluşturulmasını sağlamak

4 Proje el kitabı, iletișim matrisi, proje iletișim akıșı vb. Dokümanları oluşturmak, proje paydaşları arasında koordinasyonu sağlamak

5 Şantiyede uygun personelin çalışmasını denetlenmek

6 Malzemelerin projeye uygunluğunu ve kalitesini denetlemek

7 Atölye imalatlarını atölyede denetlemek, test ve kontrolleri yaptırmak, raporları arşivlemek

8 Yapılan imalatların fen ve sanat kurallarına, sözleşme ve eklerine, ilgili yasa, yönetmelik ile teknik şartnamelere uygunluğunu sağlamak,

9 Çizimlerde yapılan her türlü değişikliğin çizim üzerine işlenmesini kontrol etmek ve ilgili imalatın bitimini takiben yüklenici tarafından as-built çizimlerin yapılmasını sağlamak.

10 Yapılan imalatlar ile ilgili düzenli rapor vermek

11 Yap1 işlerinde iș sağlığı ve güvenliği tüzüğü esas alınarak iş güvenliğini denetlemek

12 Zaman yönetimi yapmak, iș programını güncelleyerek kontrol etmek

13 Maliyet kontrolü ve güncellemesi yapmak, olası maliyet değişiklerini önceden is sahibine bildirmek ve onay almak

14 İs sahibine haftalık ilerleme raporlarını sunmak

15 Saha toplantılarını yönetmek
}

Tablo 6. Yapım sonraki süreçte proje yönetim firmasının görevleri

\begin{tabular}{ll}
\hline Yapım sonrası sürecinde proje yönetim firmasının yaptığı çalışmalar \\
\hline 1 & Nihai metraj ve kesin hesap işlemlerinin yapılması, \\
2 & $\begin{array}{l}\text { İş süresince gerekli test çalışmalarının yapılması işin teslimine yakın } \\
\text { test, ayar, dengele ve devre alma çalışmalarının yapılması }\end{array}$ \\
3 & $\begin{array}{l}\text { Tüm projeye ait proje ve dokümanların arşivlenmesi, as-built projelerin } \\
\text { yaptırılması, eksik ve kusurlu işlerin tespiti, }\end{array}$ \\
4 & Geçici kabulün gerçekleştirilmesi, \\
5 & Geçici kabul eksiklerinin tamamlatılması, \\
6 & $\begin{array}{l}\text { Sistemlerin ve garanti belgelerinin toplanması, iş sahibine teslim } \\
\text { edilmesi }\end{array}$ \\
7 & $\begin{array}{l}\text { Bakım ve işletme el kitaplarının hazırlanması, iş sahibine teslim } \\
\text { edilmesi }\end{array}$ \\
8 Kesin kabul 'ün gerçekleştirilmesi. \\
9 Garanti süresi boyunca ortaya çıkan herhangi bir problemde \\
danışmanlık hizmeti verilmesi
\end{tabular}

\subsection{Incelenen projedeki iş değişikliği emri talepleri yönetim sisteminin aksayan yönleri}

İș sahibinin proje yönetim firmasını atlayarak direkt yüklenici ile iletişime geçerek sözlü iş değişikliği taleplerinde bulunması,

Yüklenicinin iş sahibinden sözlü aldığ bu iş değişikliği taleplerini proje yönetim firmasına ve iş sahibine yazılı olarak sunmadan ve imalata başlama onayı almadan uygulamaya başlaması,

Yüklenicinin bazı işler için ise iş değişikliği emri çalışmasını imalata başladıktan sonra onaya sunması,

İş değişikliklerine yönelik iş sahibinden onay alma süreçlerinin çok uzaması, bu durumun imalat süresini ve yüklenicinin çalışma motivasyonunu etkilemesi,

Sözleşme sonrası sahada uygulama yapılması için yayınlanan tasarımlardaki değişikliklere ilişskin tasarım gruplarından projeler arasındaki değişikliklere ilişkin gerekçeleri ile ilgili destek alınamaması, proje yönetim firmasının değişikliğin gerekçesi ve talebin haklılığ konusunu tek başına çözmeye çalışmasından dolayı değerlendirme sürecinin uzayabilmesi,

Yüklenici, sözleşme eki proje ve saha yayını yapılan projeler arasında gördüğü farklıllıklara veya iletilen taleplere yönelik oluşan iş değişikliği çalışmalarını direkt hazırlayarak proje yönetim firması onayına iletmiştir. Fakat yüklenicinin ilettiği iş değişikliği emri dokümanları incelendiğinde ve sözleşme kapsamına göre değerlendirme yapıldığında ilave iş olarak nitelendirdiği taleplerinin çoğunun aslında sözleşme ve eklerinde karşılı̆ğ olduğu ve ilave iş olmadığı tespit edilmiştir. Yüklenicinin haksız ve hatalı iş değişikliği emri talep dokümanlarını hazırlaması ve proje yönetim firmasının bu talep dokümanını inceleme ve değerlendirme süreci her iki taraf için de zaman kayıplarının yaşamasına yol açmıştır. $\mathrm{Bu}$ sebeple süreç, iş değişikliği talep dokümanlarının yüklenici tarafından hazırlanması ve onaya sunulmasından önce iş değişikliğinin konu ve gerekçesinin proje yönetim firmasına ön onay alınması adına sunulması ve talebin proje yönetim firması tarafindan uygun bulunması sonrasında yüklenicinin iş değişikliği talep dokümanlarını hazırlaması doğru olur. Böylece yanlış talepler için gereksiz yere iş değişikliği emri talep formları oluşturulmamış ve kontrolü için zaman kayıpları yaşanmamış olur. 
İş emri değiş̧ikliği maliyet artış1/azalışına sebep olduğu kadar, süre artış/azalışına da sebep olmaktadır. İmza altına alınan iş değişiklik formlarında genellikle iş değişikliğinin maliyet üzerindeki etkisi gösterilmektedir. Ancak ikinci en önemli nokta olan iş değişikliğinin proje süresine ve iş programına etkisi bu aşamada incelenmemekte olup iş sonuna bırakılmaktadır. İş sonuna gelindiğinde yükleniciden süre uzatım talebi geldiğinde ise proje yönetim firması görüş ve kararını bildirmek iç̧in geçmişi taramaya başlamaktadır. $\mathrm{Bu}$ konu ile ilgili olarak; eğer iş değişiklik formunda ilave sayfa açılıp, iş değişikliğinin iş programının hangi hattı üzerinde olduğu veya süreyi ne kadar öteleyip/geri çektiği de imza altına almış olur ise iş sonunda talep edilecek süre uzatım talepleri de net bir şekilde değerlendirilebilir. Çünkü bazı işler iş programını etkiliyor olarak görünse de aslında kritik hat üzerinde olmadığı veya paralel faaliyeti olduğu için iş gecikmesine yol açmayabiliyor. Böylece süre uzatım talebinin doğru ve gerçeğe yakın değerlendirilmesi ve değerlendirme sırasında ortaya çıkacak tartışmaların azalması sağlanabilir. Örnek projede burada bahsedilen eksiklikten ötürü süre tespitinde karar, süreyi etkileyen genel konular üzerinden verilmiştir.

Yüklenicinin imalata devam edebilmesi için iş sahibinden onay alması gereken bazı konuları iş sahibine iletmesi fakat iş sahibi yöneticilerinin yeterli yetkinlikte olmamasından ötürü karar vermekten kaçmaları, kararsız davranmaları ve onay sürecini uzatmaları imalata başlama sürecini uzatmış, işin süresini etkilemiştir.

İş değişikliği yönetim sistemi ile ilgili yüklenicinin iş değişikliğinin ortaya çıkmasından itibaren belli süreler içerisinde iş değişikliği talebinde bulunması, iş sahibi ve proje yönetim firmasının da belli süreler içerisinde yüklenicinin talebine dönüş yapması gereklidir. Fakat örnek projede herhangi bir süre kavramı dikkate alınmamıştır. $\mathrm{Bu}$ da kararların uzamasına ve gecikmelere sebep olmuştur.

\section{Bulgular ve değerlendirmeler}

\section{1 İş değişikliklerinde atlanmaması gereken önemli adımlar}

Proje yönetim firması tarafindan yapılan değerlendirmenin yüklenici ile paylaşması

- Proje yönetim firması yükleniciden gelen talep sözleşme kapsamında ise değerlendirmeye almayarak talebi reddettiğini yükleniciye bildirir. Gelen talebin sözleşme kapsamında yapılan bir değişikliğe veya sözleşme kapsamında olmayan bir iş kalemine ait olması durumunda ise yukarıda belirtilen kontrol prosedürlerini izler ve kontrolü sonrası oluşan değerlendirmesini, iş sahibinden önce yüklenici ile paylaşır.

- Yükleniciye ilettiği değerlendirmesini yüklenici de kontrol eder, varsa hatalarını düzeltir ve itirazlarını yapar.

- Yükleniciden varsa gelen düzeltme veya itirazları proje yönetim firması tarafından tekrar değerlendirilerek yüklenici ile paylaşılır.

- Yüklenici, proje yönetim firmasının son değerlendirmesi üzerinde anlaşmaya varabilir veya tekrar itiraz edebilir.

Örnek proje özelinde yüklenici, proje yönetim firması değerlendirmelerine sık sık itirazları olsa da büyük oranda talebindeki düzeltmelerini yapmış ve büyük oranda anlaşmaya varılan çalışmalar iş sahibi onayına iletilmiştir.

Yüklenici ile ortak karara varılan çalışmanın iş sahibi onayına iletilmesi

- Proje yönetim firması yüklenici ile anlaşmaya vardığı son iş değişikliği emri talep dokümanını veya yüklenicinin hala itirazda bulunduğu fakat proje yönetim firmasının son değerlendirmesini kapsayan iş değişikliği emri talep çalışmasını iş sahibi onayına sunar.

- Proje yönetim firması, anlaşmazlıkların ve hatalı değerlendirmelerin önüne geçmek için değerlendirmesini direk iş sahibine değil, önce yükleniciye iletir. Yüklenici, varsa hatalarını düzeltir veya varsa itirazını gerekçesi ile birlikte sunar. Böylece proje yönetim firması, iş değişikliği emri talep değerlendirmesini daha adilane ve iki tarafin da haklarını gözeterek sonlandırmış olur.

İş sahibinin değerlendirmesini proje yönetim firması ile paylaşması

- İş sahibi, proje yönetim firması tarafından kendisine iletilen iş değişikliği emri talep dokümanını inceler ve görüşlerini proje yönetim firmasına iletir. Proje yönetim firması, iş sahibine ilettiği değerlendirmesine iş sahibinin itiraz etmesi durumunda iş sahibi ile görüşme sağlayarak sözleşme şartları çerçevesinde talep ile ilgili detayları tekrar aktarır.

Örnek projede iş sahibi yetkilileri, proje yönetim firması tarafindan kendisine iletilen iş değişikliği emri taleplerine çeşitli sebeplerden ötürü genellikle olumsuz dönüşler yapmış olup, onay sürecini çok fazla uzatmışlardır. İş sahibi, özellikle yüklenici ile direkt iletişime geçmesi ve taleplerini sözlü olarak iletmesi sonrasında yüklenicinin ilgili işi yerine getirmesi sonrasında ek fiyat talebinde bulunduğu bazı işleri, ek fiyat geleceğini bilmediğini ileri sürerek kabul etmemiştir. Ayrıca iş sahibi yöneticilerinin yeterli yetkinlikte olmamasından ötürü karar vermekten kaçmaları ve kararsız davranmaları onay sürecini uzatmıştır.

İşs sahibi Türk yetkilileri, yaşanan değiişikliğin sebeplerini yurt dışı merkezine anlatmada da zorluk yaşamışlardır. Proje yönetim firması bu konuda iş sahibinin Türk yetkililerine destek vererek, iş değişikliği talebinin gerekçesini ve haklılığını iş sahibinin yurt dışı merkezine anlatmış olup onay süreçlerinin uzamasının önüne geçmeye çalışmıştır.

İs sahibi ve proje yönetim firmasının ortak kararının yükleniciye bildirilmesi

- Proje yönetim firması iş sahibine ilettiği değerlendirmesine iş sahibinin itiraz etmemesi ve onaylamas1 durumunda son değerlendirme kararını yükleniciye bildirir.

- Proje yönetim firması, iş sahibine ilettiği değerlendirmesine iş sahibinin itiraz etmesi durumunda iş sahibi ile görüşme sağlayarak sözleşme şartları çerçevesinde talep ile ilgili detayları tekrar aktarır ve iş sahibi ile anlaşmaya varılması durumunda değerlendirme yükleniciye bildirilir. İş sahibinin itirazlarının devam etmesi durumunda ise oluşan itirazlar ve sebepleri yüklenici ile paylaşılarak tekrar değerlendirmesi istenir. Yüklenicinin de kabul etmemesi durumunda konu anlaşmazlığa dönüşür.

Örnek projede birçok konunun anlaşmazlı̆̆a dönüşmesine rağmen, iş sonunda proje yönetim firmasının 
arabuluculuk yapması ile yüklenici ve iş sahibinin anlaşmaya varılması sağlanmıştır. Ayrıca iş sahibi Türk yetkililerinin yeterli yetkinlikte olmaması, karar vermekten kaçmaları, kararsız davranmaları ve onay sürecinde istedikleri değişikliklerin sebeplerini yurt dişı merkez ofislerine aktarmakta güçlük yaşamaları gibi sebeplerden ötürü ek fiyat taleplerinin onay süreci uzamıştır. Ancak yine de yüklenici, proje yönetim firmasının da araya girmesi ve yönlendirmesi ile kritik bazı işler için fiyat onayını beklemeden sadece işe başlama onayı ile işine devam etmiş, işin sonunda fiyat konusunda proje yönetim firmasının da desteği ile her iki tarafın hakkı gözetilerek anlaşmaya varılmıştır. Örnek projenin iş değişikliği emri yönetim sistemi akış diyagramı yolu ile Şekil 1'de özetlenmiştir.

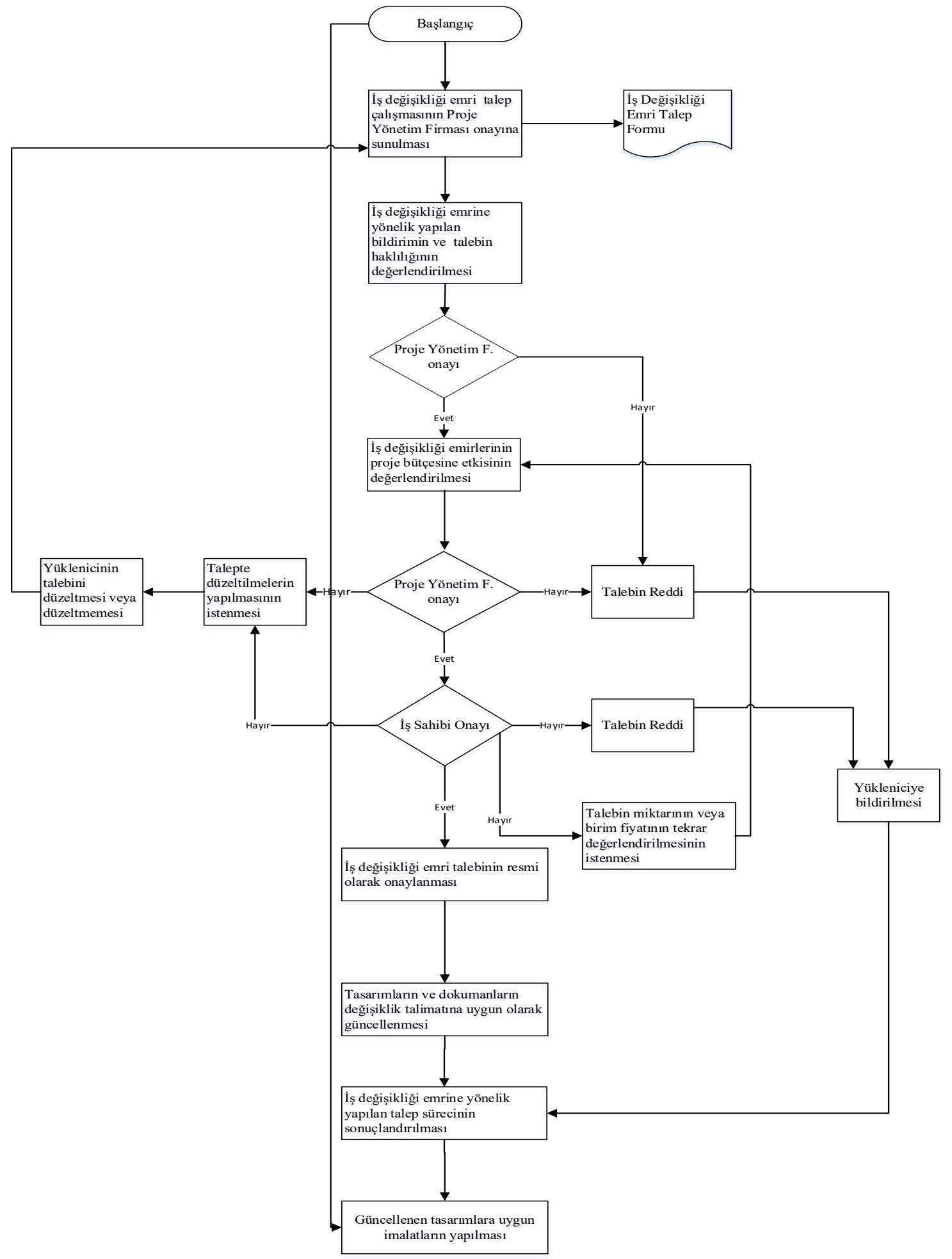

Şekil 1. Örnek projede uygulanan iş değişikliği emri yönetim sisteminin akış diyagramı 


\subsection{Yeni geliştirilmiş iş değişikliği yönetim süreci aklş} şemast

Örnek projenin hak talebi sürecindeki aksayan yönleri dikkate alınarak Şekil 2'de öneri hak talebi süreci akış diyagramı oluşturulmuştur. $\mathrm{Bu}$ önerilen akış diyagramında sunulan iş değişikliği yönetim adımlarının uygulanması halinde iş değişiklikleri sistemsel olarak değerlendirilebilecek ve arada atlanan proje tarafi olmayacaktır. Aynı zamanda önceki bölümlerde sunulan değerlendirmeler ile birlikte ele alındığında bu akış şeması iş değişikliklerinin herhangi bir projede eskiye oranla daha az talep edilmesine sebep olacaktır. Çünkü, proje yönetiminde özellikle iş değişikliklerinin yönetiminde atlanan adımlar farklı iş değişikliği taleplerine ve hak taleplerine neden olmaktadir.

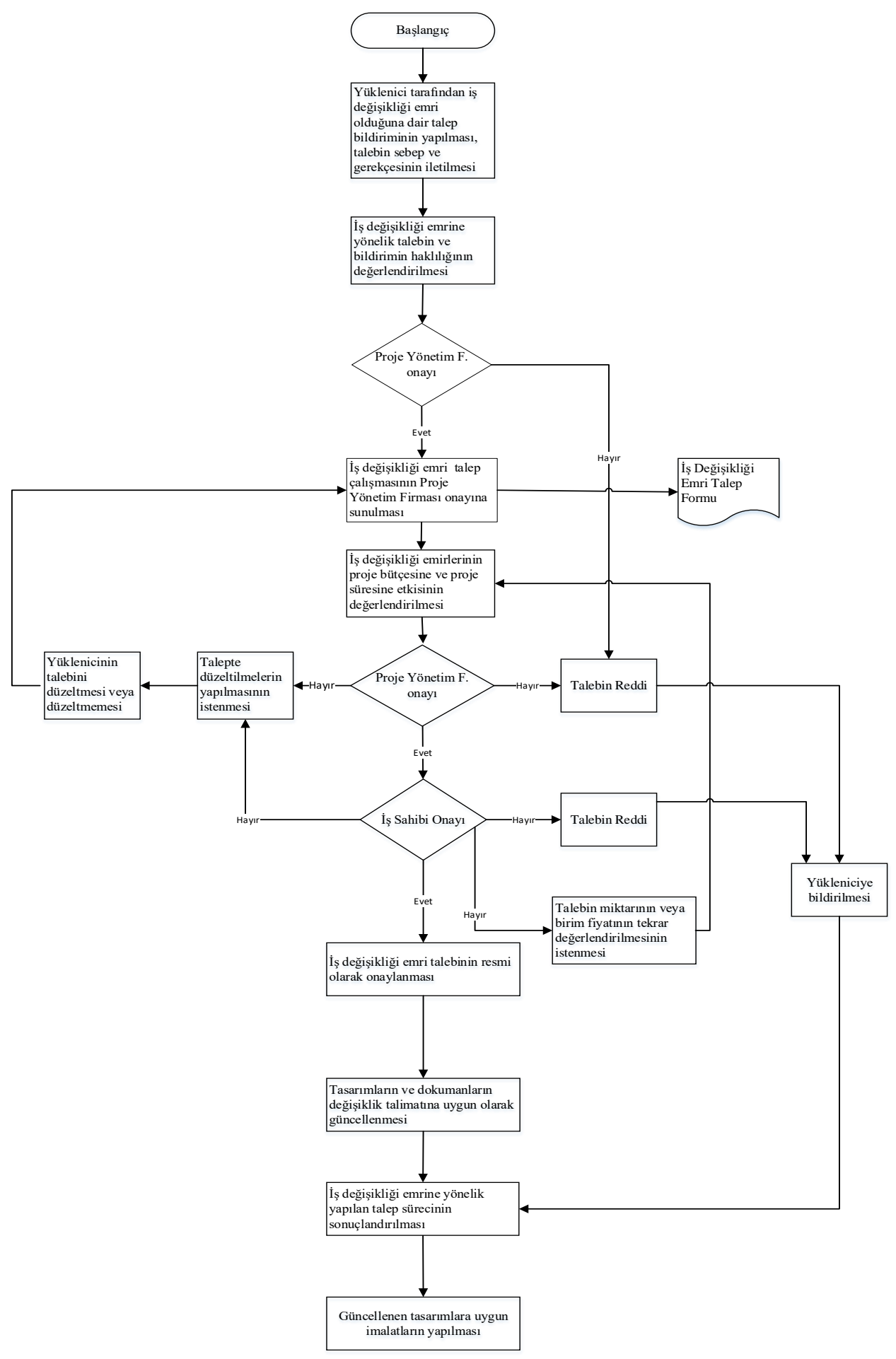

Şekil 2. Öneri talebi yönetim süreci akışşeması 
Çalışmaya başlamadan önce detaylı bilgi edinebilmek amacı ile çok sayıda yerli ve yabancı kaynaklar incelenerek literatür taraması yapılmıştır. Ayrıca, iş değişikliklerinin proje kalitesi, projedeki işgücü verimliliği, projedeki taraflar arası ilişkiler üzerinde büyük etkilerinin olduğu da tespit edilmiştir. Genel çözüm önerileri olarak, inşaat aşamasında tasarımlarda değişiklik yapılmasının durdurulması, iş kalemlerinin kırılımlı olarak gösterildiği iş planlama tekniklerinin kullanması, projenin sık1 takip edilebilmesini sağlayan haftalık ve aylık raporların yapılması gibi eylemlerin inşaat sürecinde oluşan iş değişikliği emri çalışmalarını önleyebileceği belirtilmiş ancak bir sistem önerisi getirilmemiştir.

Ardından inşaat sektöründeki proje süreçlerinde ortaya çıkan iş değişikliklerinin sebeplerini, etkilerini ve ortaya çıkması durumunda nasıl yönetileceği anlatılmaya çalışılmıştır. Bu çalışma ile iş değişikliğinin azaltılmasına yönelik bir sistem önerisi getirilmesi hedeflendiğinden proje sürecinin her safhasının detaylı olarak irdelemesi gerekmiş, projenin her safhası için iş değişikliğini meydana getirebilecek sebepler belirlenmeye çalışılmıştır. İnşaat sektöründe yaşanan iş değişikliklerinin minimize edilmesine yönelik bir örnek projede proje yönetim firmasının iş değişikliği konusundaki görevleri incelenmiş, ardından örnek projedeki iş değişikliklerinin yönetiminde yaşanan aksaklıklar vurgulanmıştır. Elde edilen veriler ile iş artış ve azalışlarını minimize etmek için hangi proje paydaşının tasarım öncesi dönemden başlayarak, inşaatın tamamlanması sonrası dönemi de kapsayacak şekilde hangi aşamada hangi önlemi alması gerektiği akış diyagramı yöntemi ile sistematik hale getirilmiştir. Oluşan bu sistem incelendiğinde, iş değişikliğini azaltmaya yönelik yapılması gereken eylemlerin 'entegre proje yönetim sistemi' 'ile uyumlu olduğu görülmüştür. Entegre proje yönetim sistemi (IPD); proje boyunca projeye dâhil olması planlanan tüm katılımcıları, projede kullanılması planlanan sistemleri, çalışma yöntemlerini, projeyi ekonomik hale getirmek, projedeki israfı azaltmak ve verimliliği arttırmak amacı ile projenin erken safhasında bir araya getiren entegre bir proje teslim yöntemi şeklidir [25]. Entegre proje yönetim sisteminin çalışma ve hedef prensiplerine dikkatlice bakıldığında bu yönetim sistemi ile yürütülmeye başlanan projelerde geleneksel yönetim sistemi ile yönetilen projelere oranla daha az sayıda iş değişikliği emri talebinin oluşacağ açıkça görülmektedir. Ancak entegre proje yönetim sistemi çalışma süreci yapım evresinin sonuna kadar olup kullanıcılar için yapıyı işletmeye aldıkları yapım sonrası süreçte karşılaştıkları sorunları ve sıkıntıları çözmeye yönelik herhangi bir çalışma yapmamaktadır. Diğer yandan bu makale çalışmasında önerilen sistem akış diyagramı, entegre proje yönetim sisteminin aksine yapım sonrası evrede de devam etmekte olup, müşteriler için güvenli, konforlu ve kaliteli proje teslimi yapılması amaçlanmıştır.

\section{Sonuç ve öneriler}

İnşaat projelerinin her türlü iç ve dış etkiye açık olmasından ve çok sayıda tarafın tek bir projede, sınırlı bir alan ve sürede kompleks bir projeyi gerçekleştirmeye çalışmasından ötürü hiçbir değişikliğe maruz kalmadan planlanan şekilde tamamlanması oldukça güçtür. Özellikle büyük ve karmaşık projelerde bu belirsizlikler proje yönetim firmalarının inşaat projelerine dahil olmasını gerekli kılmaktadır. Ancak bazı projelerde proje yönetim firmalarını dahi zorlayacak sayıda iş değişiklikleri olabilmektedir. Bu kadar çok iş değişikliği de projelerin istenilen süre, kalite ve maliyette başarıyla gerçekleştirilmesini zorlaştırmaktadır. Var olan proje yönetim sistemleri bu açıdan incelendiğinde özellikle Türkiye'deki inşaat sektöründe yaşanan iş değişikliklerini azaltma konusunda yetersiz kaldıkları görülmektedir. Şirketlerde kullanılan mevcut sistemlere iş değişikliklerinin yönetiminde atlanan adımlar farklı iş değişikliği taleplerine ve hak taleplerine neden olmaktadır. Bu makalede özellikle söz konusu açığı doldurmak amacıyla inşaat projeleri boyunca oluşan iş değişikliği emri taleplerinin azaltılmasına yönelik tasarım öncesi dönemden başlayarak, inşaatın tamamlanması sonrasındaki dönemi de kapsayacak şekilde hangi proje paydaşının hangi aşamada devreye girmesi gerektiğini gösteren bir iş emri değişikliği sistemi bir akış diyagramı kullanılarak oluşturulmuştur. Sunulan sistemde herhangi bir proje paydaşının atlanmadığı, iş değişikliklerinin adım adım ve sistematik bir yolla ele alındığının altı vurgulanmalıdır. Başından sonuna kadar tüm süreçleri incelenen örnek projenin Türkiye'de bir projede olması çalışmanın kısıtlarından birisi olarak değerlendirilmelidir. Öte yandan proje yönetim sürecinde adım adım değişiklik taleplerini değerlendirmek ve bunlara karşı atılacak adımlar konusunda tek bir firma tarafından yönetilen projelerin incelenmesi için bizzat tüm süreçlerde yer alma zorunluluğu bir kısıt olarak belirtilmelidir. Makale yazarlarından birisinin çalıştığı firma özelinde incelemeye gidilmiş, o nedenle de tüm bilgi ve belgelere ulaşılabilmiştir. Ancak, örnek projedeki bazı bilgiler gizlilik anlaşmaları nedeniyle paylaşılamamıştır. Keza, farklı tip projelerde ne gibi değişiklik taleplerinin çıkacağı hususu, bu çalışma başlangıç kabul edilerek ileride yapılacak çalışmalar için değerlendirilebilir. Ayrıca, tasarım öncesi evreden tasarım sonrası evreye kadar kullanılabilmesi ve örnek bir projeden yola çıkılarak çözümlenmesi sebebiyle bu çalışmanın literatüre ve özellikle Türk inşaat sektörüne büyük katkı yapacağına inanılmaktadır.

\section{Çıkar çatışması}

Yazarlar çıkar çatışması olmadığını beyan etmektedir.

\section{Benzerlik oranı (iThenticate): \%15}

\section{Kaynaklar}

[1] İNTES, Türkiye İnşaat Sanayicileri İşveren Sendikası, İnşaat Sektörü Raporu, 2020.

[2] A. E. Keleş ve M. K. Keleş, İnşaat sektöründe kullanımı artan bilgisayar yazılımları ve bilgi teknolojilerinin irdelenmesi. El-Cezeri Journal of Science and Engineering, 5(2), 610-617, 2018. https://doi.org/10.31202/ecjse.386469.

[3] M. Syal, J. Diffendal, D. Duah, Change order guidelines for electrical and low voltage contractors. Project Rep., ELECTRI International. Bethesda, 2014. 
[4] H. R. Thomas, M. J. Horman, R. E. Minchin Jr., and D. Chen, Improving labor flow reliability for better productivity as lean construction principle, Journal of Construction Engineering and Management.129 (3), 251-261, 2003. https://doi.org/10.1061/(ASCE)07339364(2003)129:3(251).

[5] M. Staiti, M. Othman, A. A. Jaaron, Impact of change orders in construction sector in the West Bank. In International conference on industrial engineering and operations management. Kuala Lumpur, Malezya, 8-10 Mart 2016.

[6] F. M. Arain, Strategic management of variation orders for institutional buildings: Leveraging on information technology. Project Management Journal. Dec;36(4):66-77, 2005. https://doi.org/10.1177/ 875697280503600408.

[7] I. A. Motawa, C. J. Anumba, A. El-Hamalawi, P.W. Chung, M. Yeoh., M. Sun, Development a fuzzy system for change prediction in construction projects. Inproceedings of the Xth International Conference on Computing in Civil and Building Engineering, Weimar, Germany, Jun 2 (pp. 02-04), June 2004.

[8] S. Isaac, R. Navon, Feasibility study of an automated tool for identifying the implications of changes in construction projects. Journal of Construction Engineering and Management. Feb;134(2):139-45, 2008.https://doi.org/10.1061/(ASCE)07339364(2008) 134:2(139).

[9] J. K. Ssegawa, K. M. Mfolwe, B. Makuke, B. Kutua, Construction variations: a scourge or a necessity. InProceedings of the First International Conference of CIB W107, 11-13, Nov 11, 2002.

[10] A. H. Memon, I. A. Rahman and M. F. A. Hasan, Significant causes and effects of variation orders in construction projects. Research Journal of Applied Sciences, Engineering and Technology, 7(21), 44944502, 2014.

[11] M. F. Al-Hams, Simulation model of change orders and their impact on building projects performance in Gaza strip. Master theses, The Islamic University, Gaza, 2010.

[12] S. A. Assaf, S. Al-Hejji, Causes of delay in large construction projects. International Journal of project management. 24(4), 349-357, 2006. https://doi.org/ 10.1016/j.ijproman.2005.11.010.

[13] J. Desai, J. Pitroda and J. Bhavasar, Analysis of Factor Affecting Change Order in Construction Industry Using RII Method. International Journal of Modern Trends in Engineering and Research, 2, 344-347, 2015.

[14] M. E. Abd El-Razek, H. A. Bassioni, A. M. Mobarak, Causes of delay in building construction projects in Egypt. Journal of construction engineering and management. 134(11), 831-41, 2008. https://doi.org/1 0.1061/(ASCE)07339364(2008)134:11(831).

[15] Kank Sik Wei, Causes, Effects And Methods Of Minimizing Delays In Contructıon Projects, Faculty of Civil Engineering, University Technology Malaysia. 2010.
[16] C. Charoenngam, S. T. Coquinco and B. H. W. Hadikusumo, Web-based application for managing change orders in construction projects. Construction Innovation, 3(4), 197-215, 2003. https://doi.org/ $10.1108 / 14714170310814936$.

[17] A. S. Alnuaimi, R. A. Taha, M. Al Mohsin, and A. S. Al-Harthi, Causes, effects, benefits, and remedies of change orders on public construction projects in Oman. Journal of construction engineering and management, 136(5), 615-622, 2010. https://doi.org/10.1061/ (ASCE)CO.19437862.0000154

[18] T. R. Taylor, M. Uddin, P. M. Goodrum, A. McCoy and, Y. Shan, Change orders and lessons learned: Knowledge from statistical analyses of engineering change orders on Kentucky highway projects. Journal of Construction Engineering and Management, 138(12), 1360-1369, 2012. https://doi.org/10.1061/ (ASCE)CO.19437862.0000550.

[19] O. U. Jadhav and A. N. Bhirud, An analysis of causes and effects of change orders on construction projects in Pune. International Journal of Engineering Research and General Science, 3(6), 2015.

[20] The PMI Standards Committie, A Guide to The Project Management Body of Language, 2017 edition, Newtown Square, Pensylvania, USA, 2017.

[21] G. A. Caupin, Vision of the PM Competence, VI. Project Management International Seminar, Sao Paulo, Brazil, October 4-6, 2006.

[22] International Project Management Association, Building Bridges Worldwide Between People and Competences, 2017.

[23] CMAA, Construction Management Association of America, Standard CM Services and Practice. 2nd Edn., Reston, VA, 1993.

[24] PRINCE2, Process Map, 2020, https://www. prince2.com/eur/downloads

[25] IPMA, International Project Management Association, 2020. https://www.ipma.world/integrated-projectdelivery-ipd-an-action-guide-for-leaders/

[26] PMCC, Project Management Professionals Certification Center, P2M: A Guidebook of Project and Program Management for Enterprise Innovation, Tokyo, Japan, 2008.

[27] S. O. Revay, Coping with Extras, The Revay Report., 21(2), 2002.

[28] A. T. Baxendale and T.J. Schofield, Planning and progressing project variations in; D.A. Lagfield and A. Retik, eds. The organization and management of construction: Shaping theory and practice, London: E\& FN SPON. 2, 1986.

[29] D. Turner, Standard Contracts for Building, George Godwin, England, 1984.

[30] P. Galloway, Cumulative impact. Nielsen-Wurster Communique, 2(6), 2007.

[31] H. Mokbel, G. Salazar, Assessing the parametric building model capabilities in minimizing change orders, WIT Press, 73, 2004.

[32] P. Keane, B. Sertyesilisik, A.D. Ross, Variations and change orders on construction projects. Journal of legal 
affairs and dispute resolution in engineering and construction. May, 2(2), 89-96, 2010. https://doi.org/ 10.1061/(ASCE)LA.19434170.0000016.

[33] F. M. Arain, L.S. Pheng, The potential effects of variation orders on institutional building projects. Facilities. Sep 1, 2005.

[34] E. Boot, Change order management. School planning and management, 5(1), 2005.

[35] M. T. Callahan, Construction Change Order Claims. Aspen Publishers Online, 2005.

[36] J. J. O'Brien, Construction change orders: impact, avoidance, documentation. McGraw Hill Professional, 1998.

[37] E. R. Fisk, W. D. Reynolds, Construction project administration. Wiley, 1988.
[38] A. Senouci, A. Alsarraj, M. Gunduz, N. Eldin, Analysis of change orders in Qatari construction projects, International Journal of Construction Management. 17(4), 280-92, $2017 . \quad$ https://doi.org/ 10.1080/15623599.2016.1211973.

[39] R. H. Clough, G. A. Sears, S. K. Sears, Construction project management. John Wiley \& Sons, 2000.

[40] T. Y. Hsieh, S. T. Lu, C. H. Wu, Statistical analysis of causes for change orders in metropolitan public works. International Journal of Project Management. Nov 1, 22(8), 679-86, 2004. https://doi.org/10.1016/ j.ijproman.2004.03.005.

[41] A. A. Zeitoun, G. D. Oberlender, Early warning signs of project changes. Construction Industry Institute, 91, 1993. 